\title{
Changing Trade Structure and Industrial Deepening in the Thai Economy
}

\author{
Sompote Kunnoot (Corresponding author) \\ National Institute of Development Administration \\ Bangkok, Thailand \\ Tel: 66-84-656-4341Ｅ-mail: sompote@nida.ac.th
}

Received: May 25, 2018 Accepted: June 12, 2018 Published: June 19, 2018

doi:10.5296/jad.v4i2.13200 URL: https://doi.org/10.5296/jad.v4i2.13200

\begin{abstract}
Industrial development is increasing in complexity by economic inter-dependence within an economy. Between 1975 and 2010, Thailand's industrial deepening was evidenced by an increase in average aggregate linkages. Backward linkages for manufacturing sectors is found to be above the agricultural and primary sectors as well as service sectors. Backward linkage improvement in the agricultural and primary sectors is matched by forward linkage improvement in the service sectors. Through the growth of intra-industry trade of the global supply chain, structural change is driven by the strong growth of manufacturing sectors, relative to the agricultural and primary sectors as well as the service sectors. Stationary backward and forward linkages in manufacturing sectors indicate constant reliance on imports and equally on the agricultural, primary and service sectors for input requirements and a strong reliance on export market for growth.
\end{abstract}

Keywords: Industrial deepening, input-output analysis, backward linkages, forward linkages

\section{Introduction}

Development economics advocates industrial deepening to raise the development of a country (Javorcik, 2004; Lauridsen, 2008; Shuja' et al., 2008; Yean \& Heng, 2011). Economic growth is driven more efficiently by domestic production (UNCTAD, 2013), as value added is generated by employment of labor and capital factors as well as indirect tax collection. The more domestic production a country can achieve, the greater the value added contributing to gross domestic products (GDPs) and economic growth. In contrast, production requiring large imported inputs can create comparatively small value added and contributes little to GDP and economic growth.

An economy can consist of a large number of production sectors, ranging from agricultural and primary production to simple processing industries to more complex industries and to service sectors. This wide range of sectors can engage in the transaction of inputs and outputs. They are interdependent in terms of direct and indirect input requirements and product customers. The output of one sector is the input for other sectors. Likewise, the production of sectors can require inputs of many types and sectors. These connections are called backward linkages as inputs are required from other sectors, and forward linkages as a product is required by other sectors. The output of a petroleum refinery, for example, is used by all 
sectors of an economy. Likewise, inputs for the automobile industry are drawn from many sectors. The linkages are complex, as there are indirect connections for both outputs and inputs.

If sectors of an economy are grouped by function as agricultural and primary sectors, manufacturing sectors, and service sectors, it is intuitive that for developed economies, more complex linkages would be found for manufacturing sectors compared with the agricultural and primary sectors and the service sectors. For less-developed economies, this difference may not be conclusive, as manufacturing sectors may be in their initial stage, operating in the downstream assembly of imported parts (Amirahmadi and $\mathrm{Wu}, 1995$ ). The upstream manufacturing process to supply these parts is dominated by developed economies (Riad et al., 2012). Over time, development can take less-developed countries to more upstream levels depending on the evolution of internal factors, such as learning and educational culture, innovation drive, and public policies. In terms of economic development, manufacturing sectors will be treated as the main drivers, employment generators, and targets for supportive policies (De Mello, 1997; Borensztein et al., 1998; Gorg and Greenaway, 2004; Pack, 2008; Ritchie, 2008).

The typical production of goods and services in a modern economy is an activity that combines domestically produced and imported inputs. The proportion of imported inputs can vary from a small to a large percentage. Industrial deepening is achieved by increasing the proportion of domestic inputs in the production of goods and services, thereby reducing the proportion of imported inputs. It is thought that industrial deepening evolves over time, along with greater opportunity for the substitution of imported inputs by domestically produced inputs as a country diversifies its industrial production (Chenery and Watanabe, 1958; Hirschman, 1958; Hirschman, 1977; Hirschman, 1986; van Dijck, 1987; Verbruggen, 1987; Kunnoot and Chowdhury, 1992; Schnabl, 1994; Islam and Chowdhury, 1997; Claus, 2003; Javorcik, 2004; Jabbour and Mucchielli, 2007; Rohana and Zakariah, 2007; Gangnes and Assche, 2010; Kohpaiboon, 2010).

This process is called import substitution and is often misunderstood as protectionism. Rather, it can be reasoned that import substitution is a natural process that is the evolutionary outcome of expanding and broadening export markets brought about by foreign direct investment. Overtime, production for expanding export markets generates increases in both domestic and imported inputs. The momentum created by expanding export markets opens up the opportunity for producing domestic inputs to achieve economies of scale, thus becoming more favorable relative to imported inputs. With this process of import substitution, production multiplies. This evolutionary process occurs along with trade growth and can be facilitated by policies to produce external effects such as infrastructure development, as well as human and social capital development.

From the perspective of economic development, import substitution is domestic demand-led growth, wherein the extra value added is generated by expanded production. The market for domestic production can be broadened to include final uses; i.e., consumption by households, investment, government, and the foreign markets, as well as intermediate uses for the production of other goods. The intermediate markets provide a vast opportunity for supply from both domestic and imported sources. Domestic supply can exploit the opportunities provided by new scope for value creation, as well as the expansion and extension of export markets. Support by domestic markets depends on competitive prices and non-price attributes, such as the quality and the reliability of suppliers.

Trade has become an increasingly important tool for economic development used by developing countries to exploit the external effects created by the East Asian NICs (newly 
industrialized countries) (Birdsall et al., 1993). Toward the end of the twentieth century and the beginning of the new millennium, advances in computer technology, global communication and transportation networks have transformed world trade into a global production network, thus enabling economies around the world to participate in a network of non-commodity production (Riad et al., 2012; UNCTAD, 2013; UNCTAD, 2014; WTO, 2013; WTO, 2014; Bhagwati et al., 2016). The production of goods and services draws inputs from diverse sources across the world. The growth of intra-industry trade drives the growth of global trade at a faster rate than the growth of global GDP (Ghibutiu, 2013).

Global trade has evolved over the past years into increased intra-industry trade (World Bank, 2009; Vogiatzoglou, 2017), whereby the production of intermediate goods is shared by countries participating in the international division of labor. This is evidenced by the rapid growth of the global export-GDP ratio (Dean and Sebastia-Barriel, 2004; Kunnoot, 2017). One possibility is that a participating country has greater opportunity for industrialization and income generation. In this context, the economic development of less-developed countries approximates that of developed countries, and industrial deepening takes on a global scale (Riad et al., 2012; WTO, 2014). Alternatively, the industrialization of a participating country can weaken as the proportion of intermediate goods production by a participating country decreases (Zhang and Xia, 2017). The third possibility is that a participating country maintains this proportion and growth rate along with the change in global trade. Over time, changes have been reported in the positions of countries in the global value chain (Gao, 2017; Muradovd, 2017) and in their impacts on domestic added value and job opportunities (Kong, 2017; Meng et al., 2017; Villanueva and Jiang, 2017).

Thailand is considered an active participant in global trade (Kunnoot, 2017; World Bank, 2018), as evidenced by the growth in the export-GDP ratio and the increased proportion of industrial goods in its trade structure. In this study, evidence of Thailand's industrial deepening is presented in the context of rapid growth in global trade. The evidence was produced from the computed value of backward and forward linkages from Thailand's input-output tables for the years 1975, 1980, 1985, 1990, 1995, 2000, 2005, and 2010. These indicators are used to describe Thailand's industrialization over time in the changing context of global trade and to explore options for public policies.

\section{Measuring Industrial Deepening}

A method to quantify inter-industry dependence was invented by Wassily Leontief (Leontief, 1936). Known as an input-output table, it enables a system for the computation of the effects of multipliers on the output of sectors across an economy originating from the change in final demand of any one sector. Thailand's input-output table classifies 180 sectors, comprised of 41 agricultural and primary sectors, 93 manufacturing sectors, and 46 services sectors. A schematic layout of Thailand's input-output table is shown in Figure 1.

Leontief's (1936) input-output system equation expresses total demand as consisting of two components: intermediate demand and final demand. Intermediate demand is the use of a commodity for the production of another commodity. Y denotes the column vector of the total demand for goods $\mathrm{i}=1 . .180$; A denotes the square matrix of coefficients of domestically produced intermediate inputs $\mathrm{i}=1 . .180$ for the production of goods $\mathrm{j}=1 . .180 ; \mathrm{F}$ denotes the column vector of the final demand for domestic goods $\mathrm{i}=1 . .180$; and I denotes the identity matrix with elements $\mathrm{i}=1 . .180 \times \mathrm{j}=1 . .180$. The matrix form is expressed as:

$$
Y=A Y+F
$$

The expression can be transformed into:

$$
Y=(I-A)^{-1} F \text {. }
$$


For economic application, the magnitude of change in output $\mathrm{Y}$ is predicted by the magnitude of multipliers $(I-A)^{-1}$ on change in final demand $\mathrm{F}$. The column element of $(I-A)^{-1}$ measures the multiplier of output of every commodity used as intermediate input of production following the change in the final demand of any one commodity. Thus, the column total of $(I-A)^{-1}$ measures the total change of output across an economy following a change in final demand of any one commodity. On the other hand, the row element of $(I-A)^{-1}$ measures the multiplier of the output of a commodity used as intermediate input following successive change in the final demand of the respective commodity. Thus, the row total of $(I-A)^{-1}$ measures the total change in the output of a commodity following successive change in the final demand of the respective commodity.

Leontief's multipliers can be used to identify the strength of impacts produced by an industry (Schultz, 1977). The measurement of the impacts, known as backward and forward linkages of the industry, has been pioneered by Rasmussen (1956) and Hirschman (1958) (Jones, 1976). In this study, backward and forward linkages are expressed in total multiplier values for each sector of Thailand' $\mathrm{s}$ input-output table. $R_{l j}$ denotes element $\left(\begin{array}{ll}l & A\end{array}\right)^{-1} ; L_{j}^{B}$ denotes the backward linkage values for sectors $\mathrm{j}$; and $L_{i}^{F}$ denotes the forward linkages value for sectors i. The backward linkages are found by:

and the forward linkages are found by:

$$
L_{i}^{B}=\sum_{i=1}^{Y} R_{i \mathrm{i}}
$$

Let $L^{A}$ denote the average linkages found by:

$$
E_{t}^{E}=\sum_{\xi=1}^{X} R_{i j} .
$$

$$
L^{A}=\frac{\sum_{i=2}^{N} \sum_{i=2}^{N} E_{i t}}{N}
$$

The average for linkages is the sum of all elements of $(I-A)^{-1}$ divided by the number of sectors. The change in average linkages is influenced by a change in the $R_{t j}$ value, which results from a change in intermediate input coefficients. 

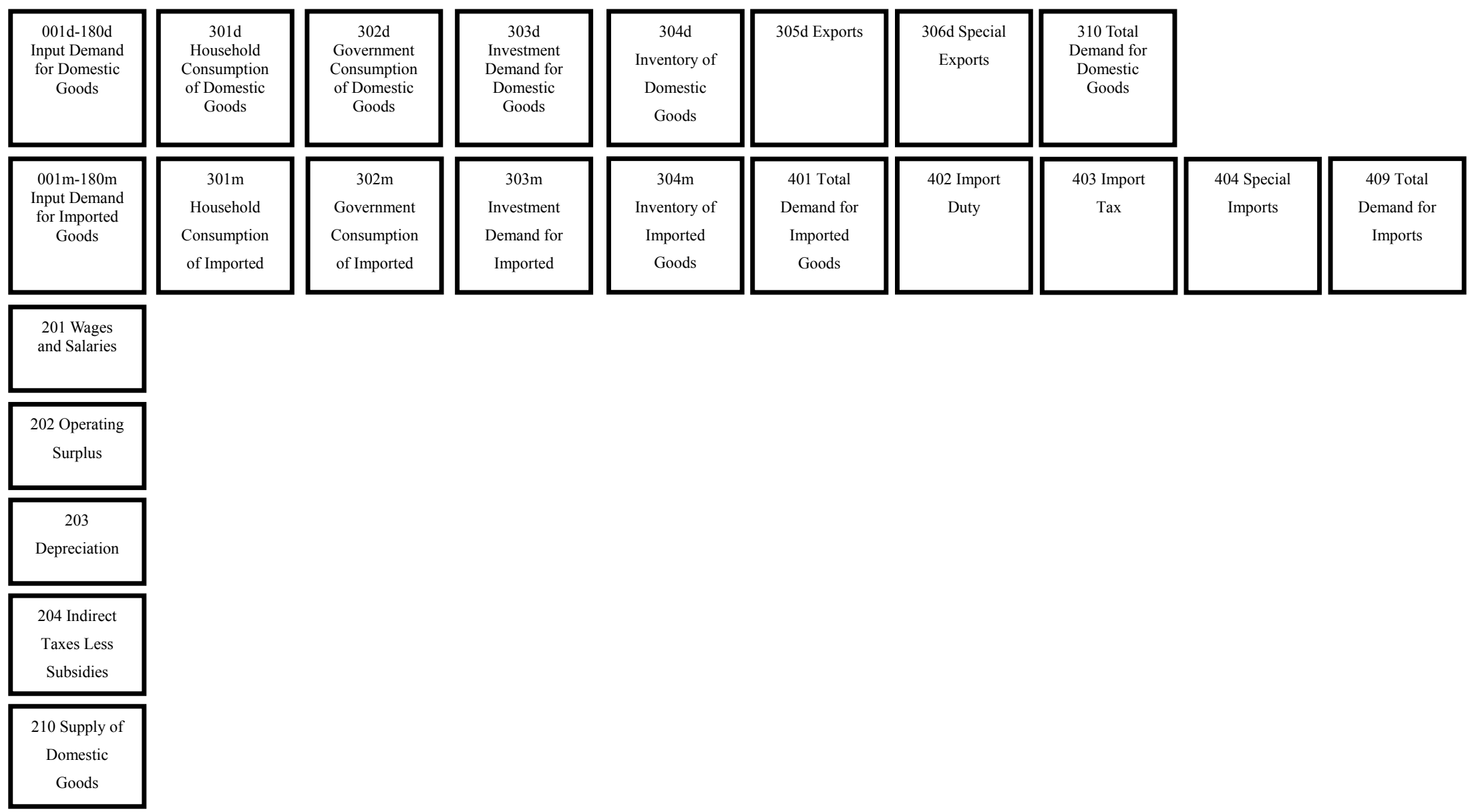

Figure 1. Layout for Thailand's input-output table.

Source: Constructed according to the structure of Thailand's input-output table. 
Backward and forward linkages for 180 sectors have been computed from Thailand's input-output tables released by the Office of National Economic and Social Development Board for the years 1975, 1980, 1985, 1990, 1995, 2000, 2005, and 2010.

Larger values of $L_{f}^{D}, L_{i}^{F}$, and $L^{A}$ are interpreted as stronger backward, forward, and average linkages, respectively, whereas an increase in value is interpreted as industrial deepening. Other things being equal, sectors with larger values of forward and backward linkages are likely to better contribute to the growth of GDP. An exception is for linkages consisting mostly of elements having a small share of the value added component of output. On the other hand, sectors consisting of less complex linkages may better contribute to the growth of GDP, as the linkages consist of elements having a large share of the value added component of output.

There are reasons for a country to expect improvement in linkages over time. The high import content of newly established industries producing finished goods creates opportunity for local enterprises to emerge to provide substitution for imported inputs. Import substitution can take advantage of scale as user industries become more diversified. Industrial establishments multiply quickly as industrial interdependence and urbanization take motion. Free trade policies and active participation in foreign trade help accelerate the establishment of the production of finished goods. Foreign direct investment to take advantage of low wages and fewer restrictions on social and environmental regulations results in diversified industries. The growth of foreign direct investments is facilitated by investment promotion measures that provide special privileges in terms of exemptions for income tax and duty for imported machinery. The growth of local banks and financing of small and medium enterprises is facilitated by foreign direct investments. The growth of public investments for infrastructures in diversified areas helps to increase the scale of infrastructural services that provide cost subsidies for production.

\section{Industrial Deepening in the Context of Trade Growth}

In the context of Thailand, despite an unstable pattern over 35 years from 1975-2010, the average linkages over 180 sectors have shown significant improvement, as shown in Table 1 and Figure 2. If sectors are grouped to comprise 41 agricultural and primary sectors, 93 manufacturing sectors, and 46 services sectors, the differences can be compared as shown in Figure 3. Over 35 years, the average backward linkages for manufacturing sectors are graphed above services sectors and agricultural and primary sectors. As a group, backward linkage development for manufacturing sectors has been relatively slow compared to that of the agricultural and primary sectors as well as services sectors.

The yearly averages for forward linkages are shown in Figure 4. Service sectors are graphed above manufacturing sectors and agricultural and primary sectors. Service sectors have shown significant improvement, whereas manufacturing, agricultural and primary sectors have shown slight improvement.

For the respective sectors, the values for backward linkages and computed improvement between 1975 and 2010 for 41 agricultural and primary sectors, 93 manufacturing sectors, and 46 service sectors are presented in Table 2 through Table 4, respectively. Differences from mean improvement $(x-\mu)$ are shown in the far-right column. For agricultural and primary sectors, outlying improvement includes other root crops, other crops for textile and matting, coffee and tea, and tungsten ore. For manufacturing, outlying improvement includes canning and preserving of meat, spinning, jute mill products, plastic ware, iron and steel, and aircraft. For service sectors, outlying improvement includes pipeline and gas distribution, air 
transport, movie theatres, radio, television, and related services.

The stationary pattern of the backward linkages of manufacturing sectors as a group can be explained by the unchanged import content of Thailand's exports over the period of rapid trade growth. Thailand has been an active participant in world trade (Kunnoot, 2017). The ratio between exports and GDP has increased from 16 percent in 1960 to 71 percent in 2008, stabilizing at approximately 69 percent from 2012 to 2016, as shown in Figure 5. As described earlier, the growth of world trade toward the end of the twentieth century and the start of the twenty-first century has been characterized by growth of intra-industry trade of the global supply chain, which has been made possible by advances in computer technology as well as decreased costs of transportation and communication. Thailand's export and import structures have shifted toward manufacturing commodities, as shown in Figure 6 and Figure 7 , respectively.

In 2015, the exports of three items of manufacturing commodities total 3,184 billion baht, which is 3.95 times the total export value for 12 items of agricultural and food commodities. These are HS 84 for nuclear reactors, boilers, machinery and mechanical appliances and parts thereof; HS 85 for electrical machinery and equipment and parts thereof; sound recorders and reproducers, television image and sound recorders and reproducers, and parts and accessories of such articles; and HS 87 for vehicles other than railway or tramway rolling-stock and parts and accessories thereof. A review of revealed comparative advantage (RCA) found that many of Thailand's exported items have gained increased share in world trade (Kunnoot, 2017).

Thailand's major sources of imports have shifted from Japan to emerging market economies (EMES) (Kunnoot, 2017; Nozaki and Shu, 2017). The shift in the structure of Thailand's exports toward significantly larger shares of manufacturing exports has been paralleled by imports of the same sectors. This explains Thailand's role in downstream industries in the global supply chain.

Table 1. Simple average of yearly aggregate linkages and structural level backward and forward linkages

\begin{tabular}{|c|c|c|c|c|c|c|c|c|}
\hline & 1975 & 1980 & 1985 & 1990 & 1995 & 2000 & 2005 & 2010 \\
\hline $\begin{array}{l}\text { Average for linkage values for } 180 \\
\text { sectors }\end{array}$ & 1.5836 & 1.5508 & 1.6099 & 1.5532 & 1.5635 & 1.6367 & 1.6642 & 1.7550 \\
\hline $\begin{array}{l}\text { Backward linkage values for } 41 \\
\text { agricultural and primary sectors }\end{array}$ & 1.2866 & 1.2755 & 1.4052 & 1.3712 & 1.3964 & 1.4905 & 1.5382 & 1.6104 \\
\hline $\begin{array}{l}\text { Backward linkage values for } 93 \\
\text { manufacturing sectors }\end{array}$ & 1.7386 & 1.7066 & 1.7293 & 1.6507 & 1.6579 & 1.7196 & 1.7344 & 1.8271 \\
\hline $\begin{array}{l}\text { Backward linkage values for } 46 \\
\text { service sectors }\end{array}$ & 1.5348 & 1.4813 & 1.5510 & 1.5182 & 1.5215 & 1.5993 & 1.6346 & 1.7381 \\
\hline $\begin{array}{l}\text { Forward linkage values for } 41 \\
\text { agricultural and primary sectors }\end{array}$ & 1.4919 & 1.4638 & 1.5694 & 1.4880 & 1.4677 & 1.4798 & 1.4809 & 1.5372 \\
\hline $\begin{array}{l}\text { Forward linkage values for } 93 \\
\text { manufacturing sectors }\end{array}$ & 1.5369 & 1.5219 & 1.5390 & 1.4609 & 1.4486 & 1.5586 & 1.5540 & 1.6285 \\
\hline $\begin{array}{l}\text { Forward linkages values for } 46 \\
\text { service sectors }\end{array}$ & 1.7595 & 1.6869 & 1.7894 & 1.7978 & 1.8810 & 1.9343 & 2.0505 & 2.2047 \\
\hline
\end{tabular}

Source: Computed from Thailand's input-output table. 
As the growth of trade is paralleled in proportion by the growth of output and imports, the stationary improvement of linkages can be seen as industrial progress as domestic contents also advance in proportion. Trade growth contribution to GDP depends on the share of value added in the output of the respective sector. It is more likely for slower growth of GDP than trade as the share of value added becomes thin.

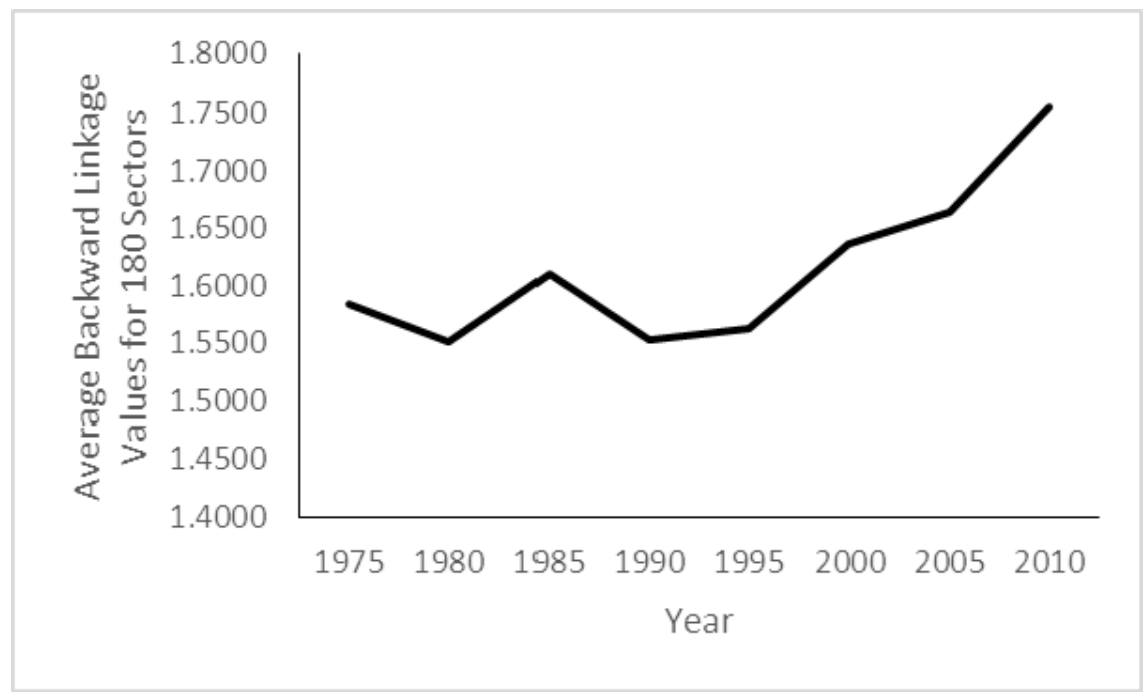

Figure 2. Simple average of yearly aggregate linkages for 180 sectors

Source: Computed from Thailand's input-output table

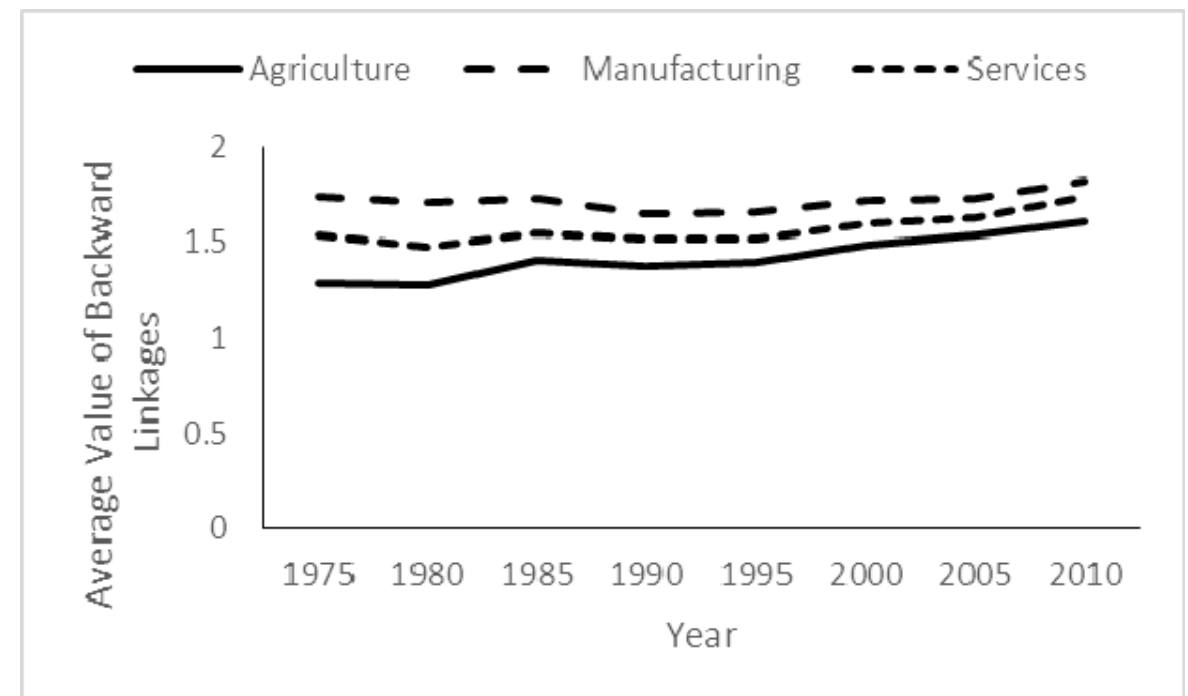

Figure 3. Average backward linkages for 41 agricultural and primary sectors, 93 manufacturing sectors, and 46 services sectors

Source: Computed from Thailand's input-output table 

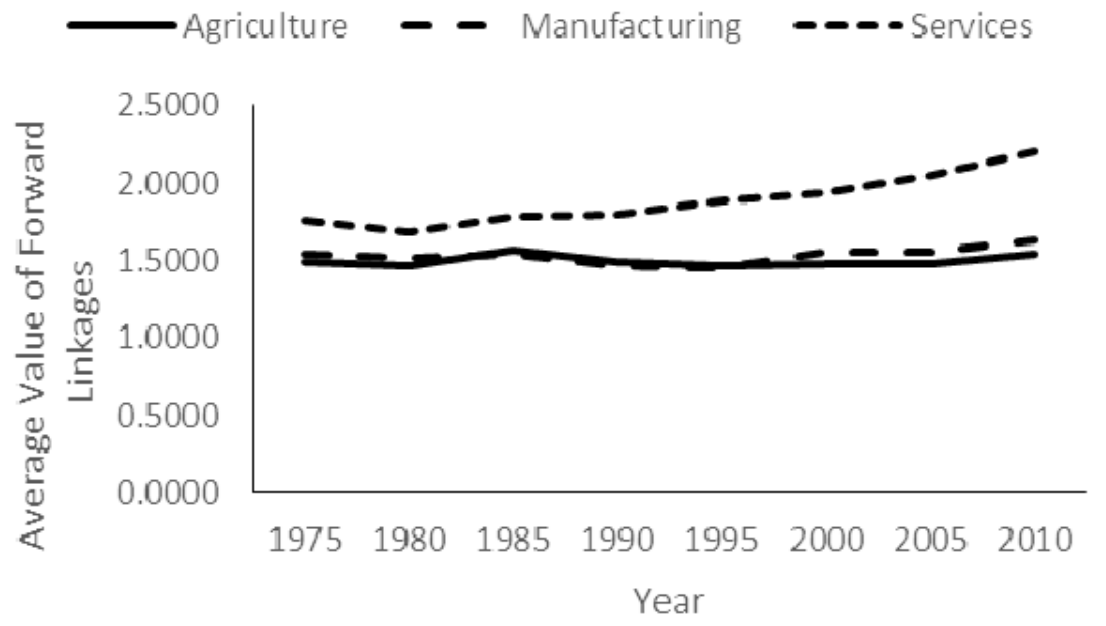

Figure 4. Average forward linkages for 41 agricultural and primary sectors, 93 manufacturing sectors, and 46 services sectors

Source: Computed from Thailand's input-output table

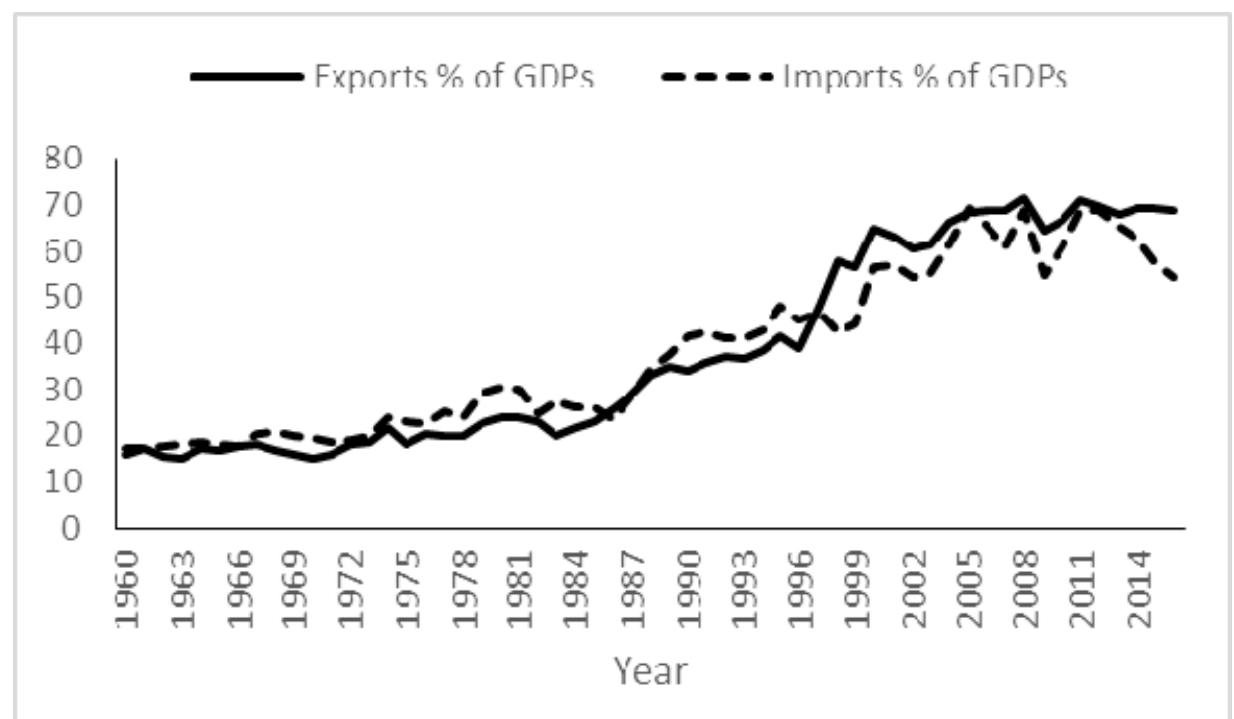

Figure 5. Thailand's exports-GDP ratios and imports-GDP ratios, 1960-2016

Source: Constructed from World Bank data. 


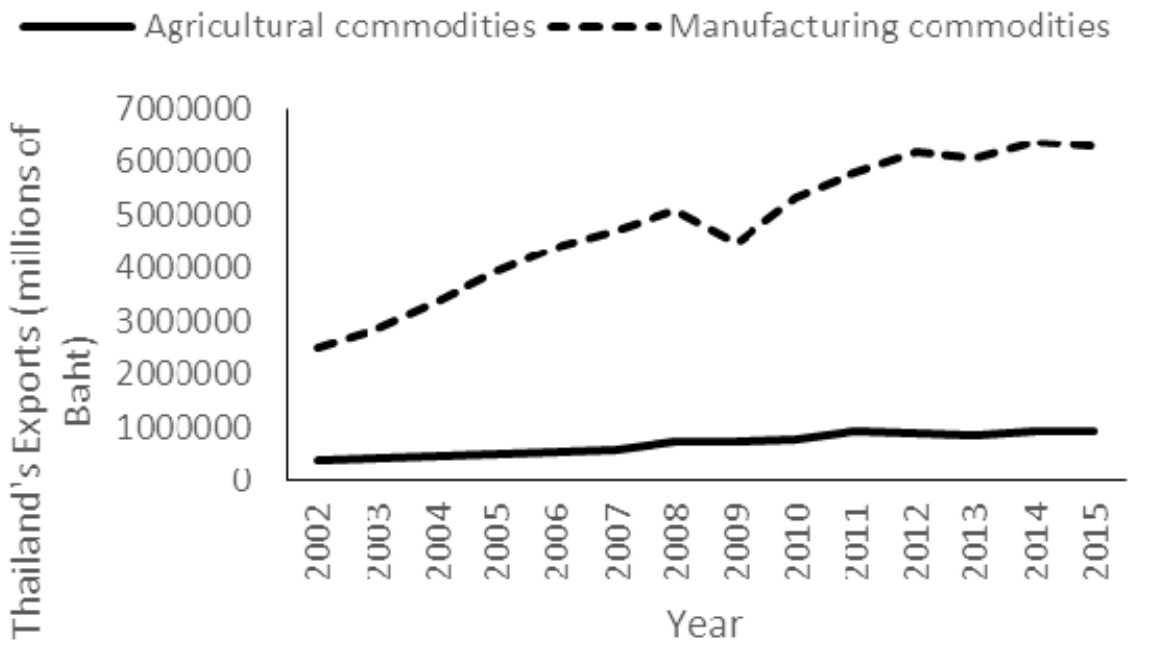

Figure 6. Thailand's exports (millions of Baht)

Source: Constructed from data released by Thailand's Ministry of Commerce

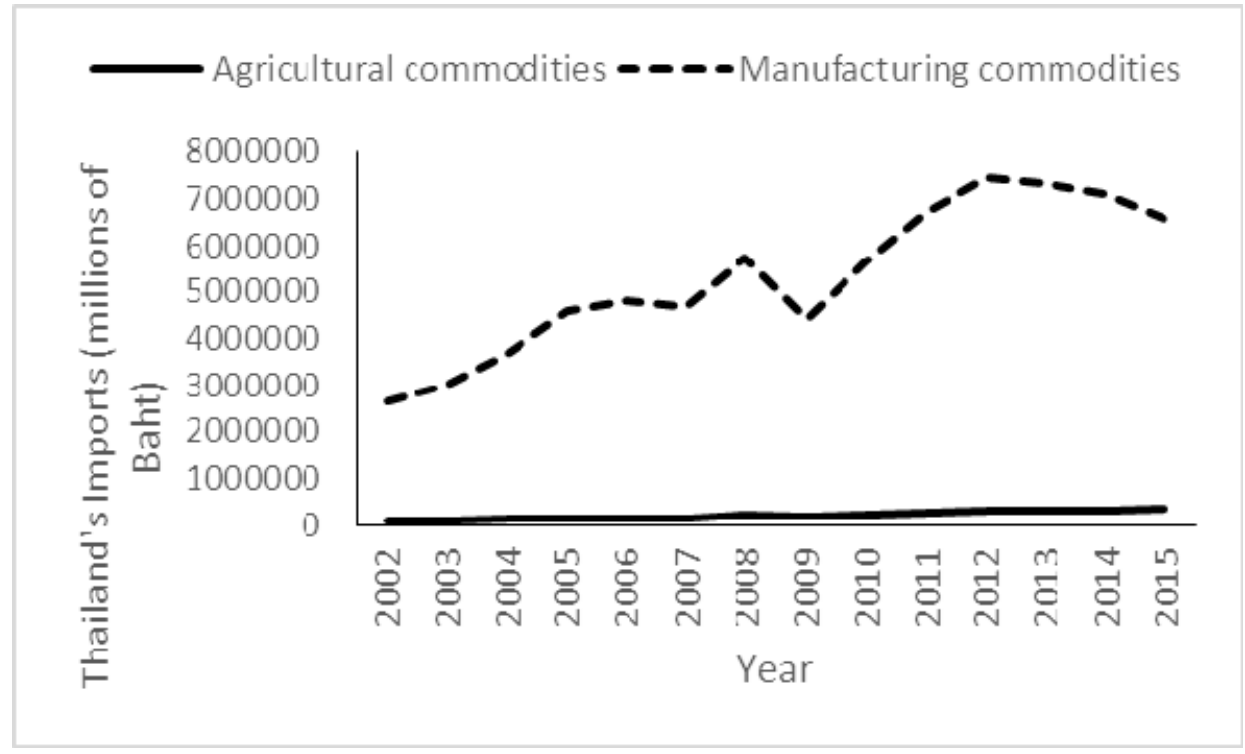

Figure 7. Thailand's imports (millions of Baht)

Source: Constructed from data released by Thailand's Ministry of Commerce 
Table 2. Backward linkages of 41 agricultural and primary sectors and differences from mean improvement ( $\boldsymbol{x}-\boldsymbol{\beta}$ ) between 1975 and 2010

\begin{tabular}{|c|c|c|c|c|c|c|c|c|c|c|}
\hline No. & Item & 1975 & 1980 & 1985 & 1990 & 1995 & 2000 & 2005 & 2010 & $x-\beta$ \\
\hline 001 & Paddy & 1.1557 & 1.1842 & 1.2185 & 1.2090 & 1.2198 & 1.2681 & 1.2740 & 1.2853 & -0.1942 \\
\hline 002 & Maize & 1.3166 & 1.3714 & 1.4676 & 1.4701 & 1.4494 & 1.3678 & 1.4963 & 1.4678 & -0.1727 \\
\hline 003 & Other cereals & 1.2414 & 1.2836 & 1.5659 & 1.4807 & 1.3749 & 1.3791 & 1.4448 & 1.5790 & 0.0139 \\
\hline 004 & Cassava & 1.1630 & 1.2153 & 1.3507 & 1.2805 & 1.3071 & 1.5134 & 1.6326 & 1.4555 & -0.0313 \\
\hline 005 & Other root crops & 1.1557 & 1.1520 & 1.2445 & 1.2377 & 1.2844 & 1.4745 & 1.3676 & 1.8701 & 0.3907 \\
\hline 006 & Beans and nuts & 1.1780 & 1.2032 & 1.4001 & 1.3368 & 1.3124 & 1.6278 & 1.4885 & 1.5204 & 0.0186 \\
\hline 007 & Vegetable & 1.1731 & 1.1861 & 1.2693 & 1.2295 & 1.2632 & 1.4314 & 1.5451 & 1.4220 & -0.0748 \\
\hline 008 & Fruits & 1.1396 & 1.1586 & 1.2387 & 1.1963 & 1.2165 & 1.3778 & 1.4058 & 1.4737 & 0.0103 \\
\hline 009 & Sugar cane & 1.2164 & 1.1939 & 1.4043 & 1.3088 & 1.3384 & 1.4266 & 1.5564 & 1.5385 & -0.0017 \\
\hline 010 & Coconut & 1.1018 & 1.0825 & 1.1344 & 1.1188 & 1.1281 & 1.1512 & 1.1609 & 1.3211 & -0.1045 \\
\hline 011 & Oil palm & 1.0955 & 1.1102 & 1.2931 & 1.3547 & 1.3005 & 1.5370 & 1.5867 & 1.6995 & 0.2802 \\
\hline 012 & Kenaf and jute & 1.1141 & 1.1351 & 1.3148 & 1.2728 & 1.3069 & 1.3470 & 1.4651 & 1.5847 & 0.1468 \\
\hline 013 & Other crops for textile and matting & 1.1410 & 1.1394 & 1.2810 & 1.2695 & 1.2642 & 1.5879 & 1.6286 & 1.7903 & 0.3255 \\
\hline 014 & Tobacco & 1.2281 & 1.2197 & 1.3652 & 1.3471 & 1.3717 & 1.4887 & 1.5866 & 1.7226 & 0.1707 \\
\hline 015 & Coffee and tea & 1.0848 & 1.0673 & 1.2819 & 1.3078 & 1.1941 & 1.4307 & 1.7319 & 1.8988 & 0.4902 \\
\hline 016 & Rubber & 1.0860 & 1.0810 & 1.1168 & 1.1227 & 1.1215 & 1.1193 & 1.1582 & 1.2551 & -0.1547 \\
\hline 017 & Other agricultural product & 1.2674 & 1.2536 & 1.3055 & 1.2807 & 1.3215 & 1.4151 & 1.4705 & 1.4577 & -0.1334 \\
\hline 018 & Cattle and buffalo & 1.2041 & 1.2080 & 1.2824 & 1.2654 & 1.3468 & 1.2972 & 1.3218 & 1.3744 & -0.1536 \\
\hline 019 & Swine & 2.1213 & 2.0911 & 2.3731 & 2.3249 & 2.3027 & 2.2371 & 2.2905 & 2.2411 & -0.2040 \\
\hline 020 & Other livestock & 1.5640 & 1.5831 & 1.7226 & 1.6905 & 1.6999 & 1.4538 & 1.4667 & 1.6899 & -0.1978 \\
\hline 021 & Poultry & 2.1825 & 1.9890 & 2.1871 & 2.1337 & 2.0769 & 2.0651 & 2.0253 & 1.9805 & -0.5258 \\
\hline 022 & Poultry products & 2.0167 & 1.8872 & 2.0135 & 1.9504 & 2.0444 & 2.1424 & 2.1305 & 2.1235 & -0.2170 \\
\hline
\end{tabular}




\begin{tabular}{|c|c|c|c|c|c|c|c|c|c|c|}
\hline \multirow[b]{2}{*}{023} & \multirow[b]{2}{*}{ Silk worm } & \multirow[b]{2}{*}{1.8320} & \multirow[b]{2}{*}{1.4851} & \multirow[b]{2}{*}{1.5330} & \multirow[b]{2}{*}{1.5209} & \multirow[b]{2}{*}{1.5524} & \multirow[b]{2}{*}{1.5296} & \multicolumn{3}{|c|}{$\begin{array}{r}\text { Journal of Asian Development } \\
\text { ISSN } 2377-9594 \\
\text { 2018, Vol. 4, No. } 2\end{array}$} \\
\hline & & & & & & & & 1.5996 & 1.2586 & -0.8972 \\
\hline 025 & Logging & 1.1952 & 1.2207 & 1.3290 & 1.2171 & 1.2550 & 1.3099 & 1.3300 & 1.3878 & -0.1312 \\
\hline 026 & Charcoal and fire-wood & 1.1223 & 1.1321 & 1.2097 & 1.1637 & 1.2008 & 1.1745 & 1.2837 & 1.3495 & -0.0967 \\
\hline 029 & Inland fishing & 1.3355 & 1.2788 & 1.5383 & 1.5346 & 1.5762 & 1.7639 & 1.7868 & 1.7820 & 0.1227 \\
\hline 030 & Coal and lignite & 1.2233 & 1.2229 & 1.3046 & 1.2766 & 1.3106 & 1.4763 & 1.4946 & 1.5684 & 0.0213 \\
\hline 031 & Petroleum and natural gas & 1.0000 & 1.0830 & 1.4253 & 1.5090 & 1.5818 & 1.4715 & 1.4998 & 1.5745 & 0.2507 \\
\hline 032 & Iron ore & 1.5111 & 1.4846 & 1.5857 & 1.5094 & 1.5013 & 1.7578 & 1.6651 & 1.8357 & 0.0008 \\
\hline 033 & Tin ore & 1.1736 & 1.1285 & 1.1991 & 1.2100 & 1.3894 & 1.5751 & 1.6165 & 1.6783 & 0.1809 \\
\hline 037 & Chemical fertilizers & 1.1624 & 1.1367 & 1.2978 & 1.2439 & 1.3219 & 1.4244 & 1.4791 & 1.5405 & 0.0544 \\
\hline 038 & Salt & 1.1381 & 1.0985 & 1.0850 & 1.0666 & 1.0650 & 1.1947 & 1.2489 & 1.3745 & -0.0874 \\
\hline 039 & Limestone & 1.3067 & 1.3024 & 1.3241 & 1.2484 & 1.2837 & 1.3537 & 1.3776 & 1.5035 & -0.1270 \\
\hline 040 & Stone quarrying & 1.3164 & 1.2964 & 1.5280 & 1.4416 & 1.4186 & 1.5128 & 1.6134 & 1.6933 & 0.0531 \\
\hline \multirow[t]{2}{*}{041} & Other mining and quarrying & 1.1497 & 1.1440 & 1.1587 & 1.1603 & 1.1917 & 1.5375 & 1.5667 & 1.6609 & 0.1874 \\
\hline & Average & 1.2866 & 1.2755 & 1.4052 & 1.3712 & 1.3964 & 1.4905 & 1.5382 & 1.6104 & -0.1942 \\
\hline
\end{tabular}

Source: Computed from Thailand's input-output table. 
Table 3. Backward linkages of 93 manufacturing sectors and differences from mean improvement $(\boldsymbol{x}-\boldsymbol{\beta})$ between 1975 and 2010

\begin{tabular}{|c|c|c|c|c|c|c|c|c|c|c|}
\hline No. & Item & 1975 & 1980 & 1985 & 1990 & 1995 & 2000 & 2005 & 2010 & $x=\mu$ \\
\hline 042 & Slaughtering & 2.5937 & 2.4034 & 2.4976 & 2.4791 & 2.5013 & 2.4209 & 2.5320 & 2.3531 & -0.3291 \\
\hline 043 & Canning and preserving of meat & 2.1989 & 2.0953 & 2.3961 & 2.3534 & 2.2999 & 2.4445 & 2.6144 & 2.6993 & 0.4120 \\
\hline 044 & Dairy products & 1.7378 & 1.9131 & 1.8851 & 1.8169 & 1.7121 & 1.8910 & 2.0113 & 2.1683 & 0.3420 \\
\hline 045 & Canning and preservation of fruit and vegetables & 1.8275 & 1.8550 & 1.8274 & 1.8469 & 1.8627 & 1.8814 & 1.9765 & 2.0430 & 0.1270 \\
\hline 046 & Canning and preservation of fish and other sea foods & 1.6934 & 1.7490 & 1.7693 & 1.6125 & 2.0088 & 2.0840 & 1.8420 & 1.9672 & 0.1853 \\
\hline 047 & Coconut and palm oil & 1.4274 & 1.5352 & 1.8692 & 1.9815 & 1.9021 & 2.2884 & 2.4007 & 2.5411 & 1.0252 \\
\hline 048 & Animal oil, animal fat, vegetable oil and by-products & 2.0154 & 2.0886 & 1.9807 & 1.9272 & 1.7448 & 1.4067 & 1.2466 & 1.2694 & -0.8345 \\
\hline 049 & Rice milling & 1.9511 & 1.9835 & 2.0733 & 2.0474 & 2.0771 & 2.0503 & 2.0996 & 2.1091 & 0.0696 \\
\hline 050 & Tapioca milling & 1.9394 & 2.0588 & 2.3177 & 2.3724 & 2.3453 & 2.5563 & 2.4270 & 2.2915 & 0.2637 \\
\hline 051 & Grinding of maize & 1.9312 & 1.9777 & 2.1038 & 1.9335 & 1.9031 & 1.9903 & 2.1275 & 2.2401 & 0.2204 \\
\hline 052 & Flour and other grain milling & 1.8249 & 1.6372 & 1.9224 & 1.5875 & 1.5608 & 1.9557 & 1.9083 & 2.0680 & 0.1546 \\
\hline 053 & Bakery products & 2.0556 & 2.0264 & 1.8642 & 1.7820 & 1.8803 & 1.9825 & 1.9213 & 2.1331 & -0.0109 \\
\hline 054 & Noodles and similar products & 2.1518 & 2.1438 & 2.2035 & 2.1872 & 2.2296 & 2.2746 & 2.2809 & 2.3568 & 0.1165 \\
\hline 055 & Sugar & 1.8525 & 1.9407 & 1.6928 & 1.9065 & 1.7699 & 1.8230 & 1.8612 & 1.8616 & -0.0794 \\
\hline 056 & Confectionery & 1.8207 & 1.6948 & 2.0390 & 1.9632 & 2.1165 & 2.1981 & 2.1075 & 2.1464 & 0.2372 \\
\hline 057 & Ice & 1.4108 & 1.5463 & 1.6614 & 1.6156 & 1.7446 & 1.6926 & 1.8035 & 1.8255 & 0.3262 \\
\hline 058 & Monosodium glutamate & 1.7160 & 1.7516 & 1.9065 & 2.0349 & 2.0930 & 2.1104 & 2.1500 & 2.2145 & 0.4101 \\
\hline 059 & Coffee and tea & 1.8002 & 1.8322 & 1.8132 & 1.8338 & 1.5947 & 2.4315 & 2.2723 & 2.1197 & 0.2311 \\
\hline 060 & Other food products & 1.7330 & 1.7435 & 1.8364 & 1.8882 & 1.9175 & 1.6760 & 1.7494 & 1.8471 & 0.0256 \\
\hline 061 & Animal feed & 2.1207 & 2.0381 & 1.9751 & 1.7555 & 1.7352 & 1.7804 & 1.6358 & 1.6127 & -0.5965 \\
\hline 062 & Distilling and spirits blending & 1.3971 & 1.4136 & 1.4090 & 1.3926 & 1.3605 & 1.8778 & 1.6203 & 1.6432 & 0.1576 \\
\hline 063 & Breweries & 1.4546 & 1.3018 & 1.3439 & 1.2955 & 1.3453 & 1.3933 & 1.4017 & 1.5144 & -0.0287 \\
\hline 064 & Soft drinks and carbonated water & 1.6094 & 1.4355 & 1.6265 & 1.7364 & 1.7929 & 1.6646 & 1.7497 & 2.0399 & 0.3420 \\
\hline 065 & Tobacco processing & 1.9165 & 1.8558 & 1.9670 & 1.8869 & 1.7962 & 1.8056 & 1.8391 & 2.0306 & 0.0256 \\
\hline
\end{tabular}




\begin{tabular}{ll}
\hline 066 & Tobacco products \\
067 & Spinning \\
068 & Weaving \\
069 & Textile bleaching, printing and finishing \\
070 & Made-up textile goods \\
071 & Knitting \\
072 & Wearing apparel \\
073 & Carpets and rugs \\
074 & Jute mill products \\
075 & Tanneries and leather finishing \\
076 & Leather products \\
077 & Footwear, except of rubber \\
078 & Saw mills \\
079 & wood and cork products \\
080 & Wooden furniture and fixtures \\
081 & Pulp, paper and paperboard \\
082 & Paper and paperboard products \\
083 & Printing and publishing \\
084 & Basic industrial chemicals \\
085 & Fertilizer and pesticides \\
086 & Petrochemical products \\
087 & Paints \\
088 & Drugs and medicines \\
089 & Soap and cleaning preparations \\
090 & Cosmetic \\
091 & Matches \\
\hline
\end{tabular}

1.3501

1.3824

$1.9036 \quad 1.9546$

$1.6609 \quad 1.5625$

$1.9831 \quad 1.9795$

$1.7579 \quad 1.8337$

$2.0646 \quad 2.1461$

$2.0126 \quad 1.9906$

$1.6830 \quad 1.5274$

$2.4234 \quad 2.3048$

$2.0151 \quad 1.8967$

2.1138

1.7309

1.7970

1.8654

1.5867

1.6924

1.5245

1.6335

1.6082

1.8729

1.6387

1.5349

1.6434

1.7959

1.9166

2.0750

1.5514

1.7503

1.7964

1.5545

1.6389

1.4821

1.4508

1.5190

1.9843

1.4772

1.4230

1.4183

1.6402

1.7627
2018, Vol. 4, No. 2

\begin{tabular}{lllllll}
1.2219 & 1.1819 & 1.1763 & 1.2066 & 1.2185 & 1.3602 & -0.0784 \\
1.4697 & 1.5588 & 1.6036 & 1.8626 & 1.7681 & 1.9493 & 0.4784 \\
1.9731 & 1.8028 & 1.7883 & 1.9030 & 1.8469 & 1.6711 & -0.3210 \\
1.6057 & 1.4856 & 1.5576 & 1.7687 & 1.7487 & 1.8567 & 0.1073 \\
2.0122 & 1.8582 & 1.8847 & 1.7855 & 1.8887 & 1.8136 & -0.2580 \\
1.7710 & 1.8196 & 1.8172 & 1.8892 & 1.7599 & 2.0097 & 0.1634 \\
1.9337 & 2.0542 & 2.0013 & 2.0766 & 2.0755 & 2.0767 & -0.0763 \\
2.0081 & 1.8038 & 1.8193 & 2.0717 & 2.1076 & 2.2229 & 0.1218 \\
1.6257 & 1.5469 & 1.5706 & 1.4113 & 1.5490 & 2.1923 & 0.4208 \\
2.5203 & 1.7927 & 1.6617 & 1.2710 & 1.4769 & 1.4215 & -1.0904 \\
1.7530 & 1.5925 & 1.5576 & 1.5619 & 1.6788 & 1.6334 & -0.4701 \\
2.2414 & 1.9191 & 1.7630 & 1.8560 & 1.8348 & 1.8101 & -0.3922 \\
1.5611 & 1.3888 & 1.3592 & 1.4257 & 1.7579 & 1.8658 & 0.0465 \\
1.7946 & 1.6714 & 1.8172 & 1.8622 & 1.9796 & 1.9277 & 0.0422 \\
1.6807 & 1.6475 & 1.5332 & 1.3969 & 1.6382 & 1.6808 & -0.2731 \\
1.4347 & 1.4137 & 1.3613 & 1.3707 & 1.4965 & 1.5649 & -0.1103 \\
1.4188 & 1.5161 & 1.5804 & 1.6335 & 1.5197 & 1.6090 & -0.1719 \\
1.3155 & 1.2793 & 1.4138 & 1.5605 & 1.6476 & 1.7046 & 0.0917 \\
1.5112 & 1.4198 & 1.4272 & 1.3978 & 1.4116 & 1.5898 & -0.1321 \\
1.3699 & 1.3188 & 1.3290 & 1.5785 & 1.4220 & 1.5706 & -0.1261 \\
1.7322 & 1.9557 & 1.9636 & 1.6436 & 1.5401 & 1.6639 & -0.2975 \\
1.5300 & 1.6918 & 1.6877 & 1.8727 & 1.9519 & 1.6092 & -0.1180 \\
1.6994 & 1.5136 & 1.4861 & 1.5731 & 1.5912 & 1.7642 & 0.1409 \\
1.5959 & 1.5951 & 1.6283 & 1.6511 & 1.5991 & 1.6502 & -0.0818 \\
1.6396 & 1.5321 & 1.3954 & 1.6329 & 1.5741 & 1.7709 & -0.1135 \\
1.6897 & 1.6629 & 1.5889 & 1.7299 & 1.7300 & 1.9266 & -0.0784 \\
\hline & & & & & &
\end{tabular}




\begin{tabular}{|c|c|c|c|c|c|c|c|c|c|c|}
\hline 092 & Other chemical products & 1.7398 & 1.4617 & 1.4724 & 1.4542 & 1.4678 & 1.5085 & 1.4964 & 1.4949 & -0.3333 \\
\hline 093 & Petroleum refineries & 1.1223 & 1.0593 & 1.2817 & 1.1114 & 1.0896 & 1.1577 & 1.0540 & 1.1521 & -0.0587 \\
\hline 094 & Other petroleum products & 1.8551 & 1.7308 & 1.5333 & 1.2005 & 1.2096 & 1.0689 & 1.7426 & 1.2954 & -0.6481 \\
\hline 095 & Rubber sheet and block rubber & 1.8318 & 1.8537 & 2.0207 & 2.0581 & 2.0220 & 1.8406 & 1.9465 & 1.9064 & -0.0139 \\
\hline 096 & Types and tubes & 1.5540 & 1.5637 & 1.8837 & 1.7314 & 1.7701 & 1.7118 & 1.7573 & 1.9111 & 0.2686 \\
\hline 097 & Other rubber products & 1.7839 & 1.7285 & 1.7383 & 1.7975 & 1.8677 & 1.7863 & 1.7987 & 1.9211 & 0.0487 \\
\hline 098 & Plastic ware & 1.2818 & 1.3815 & 1.4358 & 1.5662 & 1.7234 & 1.8611 & 1.8265 & 1.8543 & 0.4841 \\
\hline 099 & Ceramic and earthen ware & 1.6843 & 1.6157 & 1.6513 & 1.6266 & 1.7143 & 1.6384 & 1.8500 & 1.9718 & 0.1991 \\
\hline 100 & Glass and glass products & 1.7449 & 1.5361 & 1.7076 & 1.5800 & 1.5832 & 1.5596 & 1.7658 & 1.9497 & 0.1163 \\
\hline 101 & Structural clay products & 1.7093 & 1.6219 & 1.7574 & 1.7438 & 1.7001 & 1.8438 & 1.9523 & 2.1344 & 0.3366 \\
\hline 102 & Cement & 1.8074 & 1.6413 & 1.8026 & 1.6898 & 1.5832 & 1.6502 & 1.6503 & 1.8347 & -0.0612 \\
\hline 103 & Concrete and cement products & 1.9709 & 1.9596 & 1.8969 & 1.9917 & 1.8713 & 1.7753 & 1.8435 & 2.0944 & 0.0351 \\
\hline 104 & Other non-metallic products & 1.6304 & 1.7917 & 1.9365 & 1.7886 & 1.9445 & 1.9563 & 2.0147 & 2.0637 & 0.3449 \\
\hline 105 & Iron and steel & 1.3175 & 1.3463 & 1.5311 & 1.3510 & 1.3147 & 3.0860 & 3.2298 & 3.0667 & 1.6607 \\
\hline 106 & Secondary steel products & 1.6962 & 1.6784 & 1.6579 & 1.6164 & 1.3038 & 1.6975 & 1.6823 & 1.7188 & -0.0659 \\
\hline 107 & Non-ferrous metal & 1.8930 & 1.8982 & 1.8281 & 1.5631 & 1.4391 & 1.3748 & 1.3412 & 1.5051 & -0.4764 \\
\hline 108 & Cutlery and hand tools & 1.7713 & 1.5636 & 1.3757 & 1.2650 & 1.2969 & 1.4687 & 1.3713 & 1.7235 & -0.1363 \\
\hline 109 & Metal furniture and fixtures & 1.8263 & 1.6120 & 1.6267 & 1.6140 & 1.6438 & 1.4376 & 1.4394 & 1.7860 & -0.1287 \\
\hline 110 & Structure metal products & 1.6154 & 1.5043 & 1.4862 & 1.3115 & 1.3360 & 1.4020 & 1.3517 & 1.5282 & -0.1757 \\
\hline 111 & Other fabricated metal products & 1.3631 & 1.3246 & 1.4848 & 1.3876 & 1.4264 & 1.4099 & 1.3749 & 1.4818 & 0.0303 \\
\hline 112 & Engines and turbines & 1.4306 & 1.5762 & 1.6771 & 1.6855 & 1.5262 & 1.5357 & 1.7431 & 1.5446 & 0.0256 \\
\hline 113 & Agricultural machinery and equipment & 1.6477 & 1.6591 & 1.5565 & 1.5360 & 1.5932 & 1.7301 & 1.5277 & 1.6078 & -0.1283 \\
\hline 114 & Wood and metal working machines & 1.7220 & 1.6979 & 1.7813 & 1.5417 & 1.7378 & 1.6420 & 1.5165 & 1.7845 & -0.0260 \\
\hline 115 & Special industrial machinery & 1.4397 & 1.5158 & 1.4294 & 1.4386 & 1.4754 & 1.5272 & 1.4954 & 1.5146 & -0.0136 \\
\hline 116 & Office and household machinery and appliances & 1.5865 & 1.5474 & 1.5228 & 1.2193 & 1.4734 & 1.5275 & 1.4841 & 1.9470 & 0.2721 \\
\hline 117 & Electrical industrial machinery and appliances & 1.6313 & 1.6533 & 1.5510 & 1.4862 & 1.3391 & 1.4141 & 1.2967 & 1.4191 & -0.3007 \\
\hline
\end{tabular}


Radio, television and communication equipment and apparatus

2018, Vol. 4, No. 2

120 Insulated wire and cable

121 Electric accumulators and batteries

122 Other electrical apparatus and supplies

123 Ship building and repairing

124 Railroad equipment

125 Motor vehicles

126 Motor bicycle and bicycle

127 Repair of motor vehicles

128 Aircraft

129 Scientific equipment

130 Photographic and optical goods

131 Watches and clocks

132 Jewelry and related articles

133 Recreational and athletic equipment

134 Other manufactured goods

Average

$\begin{array}{ll}1.6236 & 1.711 \\ 1.8447 & 1.789 \\ 1.8379 & 1.781 \\ 1.7209 & 1.663 \\ 1.7554 & 1.450 \\ 1.6974 & 1.8917 \\ 1.3783 & 1.436 \\ 1.4752 & 1.581 \\ 1.5471 & 1.613 \\ 1.7598 & 1.726 \\ 1.4858 & 1.5045 \\ 1.5321 & 1.6193 \\ 1.7988 & 1.6396 \\ 1.9641 & 1.9396 \\ 1.2317 & 1.3176 \\ 2.0093 & 1.8376 \\ 1.9994 & 1.9457 \\ 1.7386 & 1.7066 \\ \end{array}$

1.6963

1.2558

1.1694

1.1595

1.1150

1.3519

$-0.3602$

$1.8722 \quad 1.6355$

1.5317

1.5980

1.5424

1.8170

$-0.1162$

$1.5114 \quad 1.3183$

1.3187

1.5031

1.3329

1.4677

$-0.4586$

1.5957

1.5563

1.7191

1.5851

1.5042

1.6744

$-0.1349$

$1.6141 \quad 1.5152$

1.3971

1.2197

1.7646

1.4461

$-0.3978$

1.9669

1.8360

1.7332

1.6566

1.7255

1.7939

0.0080

1.4242

1.3381

1.4274

1.8707

1.9563

1.7703

0.3035

1.7098

1.8270

13419

1.5790

0.0153

1.3000

1.8099

$1.8466 \quad 1.7546$

0.1190

$1.5929 \quad 1.2253$

1.1969

1.6938

$1.5864 \quad 1.6054$

$-0.2429$

$1.6619 \quad 1.5070$

1.5476

1.5253

1.2649

2.2202

0.6459

$1.7699 \quad 1.7023$

1.4266

1.5249

1.2987

1.4246

$-0.1960$

$1.6918 \quad 1.6228$

1.6947

1.4488

1.5175

.4893

$-0.3980$

$1.3754 \quad 1.4154$

1.6068

1.5480

1.3573

$-0.2776$

$1.8617 \quad 1.8124$

1.9150

1.9114

1.8719

0.3152

$1.9209 \quad 1.8028$

1.8040

1.7339

1.6723

$-0.0469$

1.7293

1.6507

1.7196

1.7344

1.8271

$-0.3291$

Source: Computed from Thailand's input-output table. 
Table 4. Backward linkages of 46 service sectors and differences from mean improvement $(\boldsymbol{x}-\boldsymbol{\beta}$ ) between 1975 and 2010.

2018, Vol. 4, No. 2

\begin{tabular}{|c|c|c|c|c|c|c|c|c|c|c|}
\hline No. & Item & 1975 & 1980 & 1985 & 1990 & 1995 & 2000 & 2005 & 2010 & $x-\beta$ \\
\hline 135 & Electricity & 1.7252 & 1.3264 & 1.7928 & 1.8562 & 1.6394 & 1.6849 & 1.6184 & 1.7264 & -0.2021 \\
\hline 136 & Pipe line and gas distribution & 1.0000 & 1.0000 & 2.0938 & 2.3716 & 2.3343 & 2.2790 & 2.2573 & 2.3689 & 1.1656 \\
\hline 137 & Water work and supply & 1.6078 & 1.4938 & 1.3427 & 1.2980 & 1.3353 & 1.3720 & 1.4921 & 1.5592 & -0.2519 \\
\hline 138 & Residential building construction & 1.8932 & 1.9062 & 1.8912 & 1.6890 & 1.7117 & 1.7764 & 1.8867 & 1.9406 & -0.1559 \\
\hline 139 & Non-residential building construction & 1.8723 & 1.8367 & 1.9111 & 1.7019 & 1.6689 & 1.9850 & 2.0030 & 2.0789 & 0.0034 \\
\hline 140 & Public works for agriculture and forestry & 1.7292 & 1.7132 & 1.9393 & 1.8963 & 1.8483 & 1.6751 & 1.6957 & 1.9732 & 0.0406 \\
\hline 141 & Non-agriculture public works & 1.7747 & 1.8998 & 1.9208 & 1.9532 & 1.8421 & 1.9550 & 2.0212 & 2.1977 & 0.2197 \\
\hline 142 & Construction of electric plants & 1.9008 & 1.9012 & 1.8131 & 1.7195 & 1.7072 & 1.8585 & 1.6679 & 1.9150 & -0.1890 \\
\hline 143 & Construction of communication facilities & 1.5523 & 1.6335 & 1.7536 & 1.6077 & 1.5379 & 1.5602 & 1.4496 & 1.7662 & 0.0106 \\
\hline 144 & Other construction & 1.7935 & 1.7700 & 1.6540 & 1.6087 & 1.5491 & 1.6188 & 1.6819 & 1.7937 & -0.2031 \\
\hline 145 & Wholesale trade & 1.2576 & 1.2179 & 1.2842 & 1.3009 & 1.3443 & 1.3107 & 1.3303 & 1.3738 & -0.0871 \\
\hline 146 & Retail trade & 1.2822 & 1.2338 & 1.2813 & 1.2900 & 1.3029 & 1.2645 & 1.2867 & 1.2761 & -0.2093 \\
\hline 147 & Restaurants and drinking places & 1.7557 & 1.6637 & 1.9174 & 1.9493 & 1.9328 & 1.9290 & 1.9578 & 2.0482 & 0.0892 \\
\hline 148 & Hotels and places of loading & 1.6958 & 1.5844 & 1.7332 & 1.6858 & 1.7423 & 1.7871 & 1.9263 & 2.0230 & 0.1239 \\
\hline 149 & Railways & 1.6844 & 1.9749 & 1.5897 & 1.6744 & 1.6268 & 1.5354 & 1.5880 & 1.7282 & -0.1595 \\
\hline 150 & Road passenger transport & 1.7064 & 1.6199 & 1.6025 & 1.5745 & 1.6391 & 1.9487 & 1.9228 & 1.9224 & 0.0128 \\
\hline 151 & Road freight transport & 1.6648 & 1.6778 & 1.5672 & 1.5300 & 1.6468 & 2.0885 & 1.9771 & 1.9995 & 0.1314 \\
\hline 152 & Land transport support service & 1.5351 & 1.5130 & 1.4579 & 1.2841 & 1.2613 & 1.2596 & 1.2806 & 1.3571 & -0.3814 \\
\hline 153 & Ocean transport & 1.7337 & 1.7551 & 1.1707 & 1.2952 & 1.4216 & 1.7927 & 1.6751 & 1.7036 & -0.2334 \\
\hline 154 & Coastal and inland water transport & 1.3105 & 1.4435 & 1.4937 & 1.3337 & 1.3554 & 1.4670 & 1.5494 & 1.6539 & 0.1401 \\
\hline 155 & Water transport services & 1.4257 & 1.6303 & 1.2550 & 1.1368 & 1.1954 & 1.3716 & 1.4203 & 1.4389 & -0.1900 \\
\hline 156 & Air transport & 1.6385 & 1.4243 & 1.4580 & 1.6617 & 1.7212 & 1.9308 & 1.8477 & 2.2507 & 0.4090 \\
\hline 157 & Other services & 1.5175 & 1.4192 & 1.6286 & 1.5905 & 1.6294 & 1.7181 & 1.7001 & 1.9289 & 0.2082 \\
\hline 158 & Storage and warehousing & 1.5504 & 1.4121 & 1.4818 & 1.4254 & 1.4753 & 1.5641 & 1.6626 & 1.7305 & -0.0231 \\
\hline
\end{tabular}




\begin{tabular}{|c|c|c|c|c|c|c|c|c|c|c|}
\hline 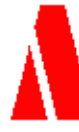 & $\begin{array}{l}\text { Macrothink } \\
\text { mstitute }\end{array}$ & & & & & & & & $\begin{array}{r}\text { of Asian } \\
\text { ISS } \\
2018\end{array}$ & $\begin{array}{l}\text { velopment } \\
2377-9594 \\
4, \text { No. } 2\end{array}$ \\
\hline 159 & Post and telecommunication & 1.4775 & 1.4330 & 1.2916 & 1.1872 & 1.2265 & 1.4527 & 1.6402 & 1.6720 & -0.0088 \\
\hline 161 & Life insurance services & 1.4100 & 1.3199 & 1.2595 & 1.1577 & 1.1622 & 1.3271 & 1.3183 & 1.3649 & -0.2484 \\
\hline 162 & Other insurance services & 1.3496 & 1.2561 & 1.3008 & 1.2643 & 1.2744 & 1.3514 & 1.3235 & 1.3415 & -0.2114 \\
\hline 163 & Real estate & 1.1635 & 1.2111 & 1.1959 & 1.1910 & 1.2351 & 1.1573 & 1.2277 & 1.3322 & -0.0346 \\
\hline 165 & Public administration & 1.0000 & 1.0000 & 1.0000 & 1.0000 & 1.0000 & 1.0000 & 1.0000 & 1.0000 & -0.2033 \\
\hline 166 & Sanitary and similar services & 1.2041 & 1.1499 & 1.3196 & 1.2734 & 1.2695 & 1.4340 & 1.4542 & 1.5158 & 0.1084 \\
\hline 167 & Education & 1.1433 & 1.2402 & 1.1787 & 1.2200 & 1.1965 & 1.2471 & 1.3295 & 1.4265 & 0.0799 \\
\hline 168 & Research & 1.3302 & 1.2214 & 1.4329 & 1.3899 & 1.4022 & 1.4663 & 1.4572 & 1.4901 & -0.0434 \\
\hline 169 & Hospital & 1.4620 & 1.3932 & 1.4458 & 1.4495 & 1.4303 & 1.4908 & 1.5292 & 1.7217 & 0.0564 \\
\hline 174 & Radio, television and related services & 1.3673 & 1.2332 & 1.5238 & 1.5787 & 1.6461 & 1.8293 & 1.9924 & 2.0487 & 0.4782 \\
\hline 175 & Libraries and museums & 1.6489 & 1.3741 & 1.4392 & 1.4382 & 1.3388 & 1.3990 & 1.4457 & 1.4723 & -0.3800 \\
\hline 176 & Amusement and recreation & 1.4817 & 1.4283 & 1.4414 & 1.2253 & 1.3080 & 1.3303 & 1.3800 & 1.4358 & -0.2491 \\
\hline 177 & Repair not classified elsewhere & 2.0434 & 1.4965 & 1.7347 & 1.5987 & 1.7444 & 1.9349 & 1.7035 & 1.9047 & -0.3419 \\
\hline 178 & Personal service & 1.2922 & 1.2242 & 1.2328 & 1.2011 & 1.1908 & 1.3932 & 1.4962 & 1.7291 & 0.2336 \\
\hline 179 & Other service not classified elsewhere & 1.0000 & 1.0000 & 1.0000 & 1.0000 & 1.0000 & 1.0000 & 1.0000 & 1.0000 & -0.2033 \\
\hline \multirow[t]{2}{*}{180} & Unclassified & 2.5816 & 2.4868 & 2.5793 & 2.2167 & 2.3736 & 2.0321 & 2.2921 & 2.2900 & -0.4948 \\
\hline & Average & 1.5348 & 1.4813 & 1.5510 & 1.5182 & 1.5215 & 1.5993 & 1.6346 & 1.7381 & -0.2021 \\
\hline
\end{tabular}

Source: Computed from Thailand's input-output table 


\section{Conclusion}

At the aggregate level, a change in Thailand's industrial deepening from 1975 to 2010 is evidenced by increases in yearly average aggregate linkages. At the structural level from 1975-2010, average backward linkages for 93 manufacturing sectors are measured above the 41 agricultural and primary sectors and 46 service sectors. Average forward linkages for the 46 service sectors are measured above the 93 manufacturing sectors and 41 agricultural and primary sectors.

Increases in yearly average aggregate linkages are contributed to by strong improvements in the agricultural and primary sectors as well as service sectors relative to manufacturing sectors. In comparison, the growth of manufacturing sectors is stronger relative to agricultural and primary sectors. While yearly average backward and forward linkages for manufacturing sectors are viewed as rather stable from 1975 to 2010, increases in backward linkages for agricultural and primary sectors are viewed as matching the increases in forward linkages of service sectors. This means that increases in the input requirements of agricultural and primary sectors is supported by service sectors rather than by manufacturing sectors.

Stable backward linkages for manufacturing sectors means that the strong growth of manufacturing exports maintains a ratio of input requirements from imports, agricultural and primary sectors, and service sectors. On the other hand, stable forward linkages for manufacturing sectors means that the strong growth of manufacturing sectors is supported by exports rather than by domestic demand. The strong growth of manufacturing sectors is seen as coupled with industrial deepening. Stable linkages in the context of growth of output driven by growth of trade is a context for two moving objects. Progress is measured by the distance covered by the moving objects. For manufacturing sectors, the growth of output is paralleled by the growth of domestic input requirements, keeping stable backward linkages. The growth of the Thai economy is strongly contributed to by growth in manufacturing exports relative to agricultural and primary exports.

Future improvement of linkages can be expected to approach the limit sooner, as manufacturing production enjoys intra-industry trade of the global supply chain. For Thailand, the future growth of the rest of its economy, largely service sectors, which account for 55 percent of Thailand's GDP, would likely be driven by structural change dominated by the growth in manufacturing sectors through trade.

\section{Acknowledgement}

The research article entitled "Changing Trade Structure and Industrial Deepening in the Thai Economy" is interpretative results and conclusion from the research entitled "Study of Industrial Self-reliance, Trade structure and Factors Driving the Growth of Gross Domestic Products of Thailand" funded by National Research Council of Thailand (NRCT) in 2015.

\section{References}

Amirahmadi, H., \& Wu, W. (1995). Export processing zones in Asia. Asian Survey, 35(8), 828-44. https://doi.org/10.2307/2645785 
Bhagwati, J., Krishna, P., \& Panagariya, A. (2016). The world trade system today. In J. Bhagwati, et al. (Eds.). The World Trade System: Trends and Challenges. Cambridge: MIT Press.

Birdsall, N. M., Campos, J. E. L., Kim, C.-S., Corden, W. M., MacDonald, L. [editor]; Pack, H., Page, J., Sabor, R. \& Stiglitz, J.E. (1993). The East Asian miracle: economic growth and public policy: Main report (English). A World Bank policy research report. New York, New York: Oxford University Press. Retrieved http://documents.worldbank.org/curated/en/975081468244550798/Main-report

Borensztein, E., Gregorio, J. D., \& Lee, J. W. (1998). How does foreign direct investment affect economic growth? Journal of International Economics, 45(10), 115-35. https://doi.org/10.1016/S0022-1996(97)00033-0

Chenery, H. B., \& Watanabe, T. (1958). International comparison of the structure of production. Econometrica. 26, 487-521. https://doi.org/10.2307/1907514

Claus, I. (2003). New Zealand's production structure: An international comparison. NZ Treasury Working Paper 03/16.

De Mello, L. (1997). Foreign direct investment in developing countries and growth: A selective survey. Journal of Development Studies. 34, 1-34. https://doi.org/10.1080/00220389708422501

Dean, M., \& Sebastia-Barriel, M. (2004). Why has world trade grown faster than world output? Bank of England Quarterly Bulletin. Autumn 2004. Retrieved May 21, 2018, from http://www.columbia.edu/ md3405/Other_Paper_1.pdf

Gangnes, B., \& Assche, A. V. (2010). Global production networks in electronics and intra-Asian trade. Working Paper No. 10-4, University of Hawaii at Manoa. https://doi.org/10.2139/ssrn.1587978

Gao, X. (2017). Relative advantage production position and applications. 25th International Input-Output Conference \& 7th Edition of the International School of I-O Analysis, June 19-23, 2017, Atlantic City, New Jersey, USA.

Ghibutiu, A. (2013). The changing landscape of international trade. Romanian Economic and Business Review. 8(2).

Gorg, H., \& Greenaway, D. (2004). Much ado about nothing? Do domestic firms really benefit from foreign direct investment? The World Bank Research Observer, 19(2), 171-97. https://doi.org/10.1093/wbro/lkh019

Hirschman, A. O. (1958). The strategy of economic development. New Haven: Yale University Press.

Hirschman, A.O. (1977). A generalized linkage approach to development, with special reference to Staplesí, in M. Nash (ed.), Essays on economic development and cultural change in honour of Bert F. Hoselitz, Economic development and cultural change, 15(Supplement). 


\section{MInstitute ${ }^{\text {Macrothink }}$}

Hirschman, A. O. (1986). Linkages in economic development, in Rival views of market society and other recent essays. New York: Elisabeth Sifton Books - Viking.

Islam, I., \& Chowdhury, A. (1997). Asia pacific economies: a survey. London: Routledge.

Jabbour, L. \& Mucchielli, J. L. (2007). Technology transfer through vertical linkages: The case of the Spanish manufacturing industry. Journal of Applied Economics, 10(1), 115-36.

Javorcik, B. S. (2004). Does foreign direct investment increase the productivity of domestic firms? In search of spillovers through backward linkages. The American Economic Review. 94(3), 605-27. https://doi.org/10.1257/0002828041464605

Jones, L. P. (1976). The measurement of Hirschmanian linkages. Quarterly Journal of Economics. 90(2), 323-333. https://doi.org/10.2307/1884635

Kohpaiboon, A. (2010). Trade policy, industrialization, and developmental challenges: Experiences of Thailand. Paper presented at GEP workshop on trade policies and industrialization in Southeast Asia: What has happened and where do we go from here, hosted by the Leverhulme Centre for Research on Globalization and Economic Policy (GEP), University of Nottingham, Malaysia, 14 October, Kuala Lumpur Teaching Centre, the University of Nottingham Malaysia Campus.

Kong, Y. (2017). How does China's Labor Productivity Change as GVC Participation Deepening. 25th International Input-Output Conference \& 7th Edition of the International School of I-O Analysis, June 19-23, 2017, Atlantic City, New Jersey, USA.

Kunnoot, S. \& Chowdhury, A. (1992). Export-oriented industrialization and industrial deepening in Thailand: An input-output perspective. Economic bulletin for Asia and the Pacific, XLIII(1), 52-62.

Kunnoot, S. (2017). Dynamics of changing Thailand's trade structure in the context of changing world trade structure. Economics and Public Policy Journal. [in Thai], 8(16), 47-66.

Lauridsen, L. S. (2008). State, institutions and industrial development. Shaker Verlag.

Leontief, W. (1936). Quantitative input and output relations in the economic system and the United States. The review of economics and statistics. XVIII (3), 105-125. https://doi.org/10.2307/1927837

Meng, B., Ye, M., \& Wei, S-J. (2017). Smile curves in global value chains: creation and distribution of value-added and job opportunities. 25th International Input-Output Conference \& 7th Edition of the International School of I-O Analysis, June 19-23, 2017, Atlantic City, New Jersey, USA.

Muradovd, K. (2017). Determinants of country positioning in global value chains. 25th IIOA Conference in Atlantic City. 25th International Input-Output Conference \& 7th Edition of the International School of I-O Analysis, June 19-23, 2017, Atlantic City, New Jersey, USA.

Nozaki, K., \& Shu, J. (2017). FDI directed to Thailand by Chinese enterprises for 


\section{Ml Macrothink}

Journal of Asian Development

ISSN 2377-9594

2018, Vol. 4, No. 1

circumlocutory export. Journal of Asian Development, 3(2), 43-59. https://doi.org/10.5296/jad.v3i2.11116

Pack, H. (2008). Asian successes vs. middle eastern failures: The role of technology transfer in economic Development. Issues in Science and Technology. Retrieved March 6, 2017, from http://issues.org/24-3/pack/

Rasmussen, P. N. (1956). Studies in Inter-sectoral Relations. Amsterdam: North-Holland.

Riad, N., Errico, L., Henn, C., Saborowski, C., Saito, M., \& Turunen, J. (2012). Changing Patterns of global trade. IMF [International Monetary Fund]. Departmental Paper No. 12/01.

Ritchie, B. (2008). Economic upgrading in a state-coordinated, liberal market economy. Asia Pacific Journal of Management, 26(3), 435-57. https://doi.org/10.1007/s10490-008-9089-0

Rohana, K. \& Zakariah A. R. (2007). Structural change, linkages vs. leakages in the Malaysian economy: 1991-2000. Paper presented at the 16th International Conference on Input-Output Techniques. 2-6 July. Retrieved May 15, 2017, from www.iioa.org/Conference/16thdownable percent20paper.html.

Schnabl, H. (1994). The evolution of production structures, analyzed by a multi-layer procedure. Economic Systems Research, 6(1), 51-68. https://doi.org/10.1080/09535319400000004

Schultz S. (1977). Approaches to identifying key sectors empirically by means of input-output analysis. Journal of Development Studies, 14. https://doi.org/10.1080/00220387708421663

Shuja', N., Wah, Y.B., Lazim, M.A., \& Okamoto, N. (2008). Identifying key sectors of Malaysian economy: a comparison of unweighted and weighted approaches. Journal of the Department of Statistics, 1, 11-26.

UNCTAD [United Nations Conference on Trade and Development] (2013). World investment report 2013: Global value chains: Investment and trade for development. Retrieved August 8, 2016, from http://unctad.org/en/PublicationsLibrary/wir2013_en.pdf

UNCTAD [United Nations Conference on Trade and Development] (2014). Trade and development report, 2014: Global governance and policy space for development. RetrievedAugust 8, 2016, from http://unctad.org/en/PublicationsLibrary/tdr2014_en.pdf

van Dijck, P. (1987). Causes and characteristics of export-oriented industrialization. in H. Linnemann, (ed.) Export-oriented industrialization in developing countries. Manila: Singapore University Press, for Council for Asian Manpower Studies.

Verbruggen, H. (1987). Gains from export-oriented industrialization with special reference to South East Asia. in H. Linnemann, (ed.), Export-oriented industrialization in developing countries. Manila: Singapore University Press, for Council for Asian Manpower Studies.

Villanueva, L., \& Jiang, X. (2017). The Myth of Benefit of Trade: the case of Mexico manufacturing sector. 25th International Input-Output Conference \& 7th Edition of the 
International School of I-O Analysis, June 19-23, 2017, Atlantic City, New Jersey, USA.

Vogiatzoglou, K. (2017). International production sharing and export development: An examination for China and Vietnam. Journal of Asian Development, 3(2), 196-212. https://doi.org/10.5296/jad.v3i2.11561

World Bank (2009). Reshaping economic geography. World Development Report 2009. Retrieved May 21, 2018, from http://documents.worldbank.org/curated/en/730971468139804495/pdf/437380REVISED01B LIC1097808213760720.pdf

World Bank. (2018). World development indicators. Retrieved May 21, 2018, from http://databank.worldbank.org/data/reports.aspx?source=world-development-indicators

WTO [World Trade Organization]. (2013). World trade report 2013: Factors shaping the future of world trade. WTO Publications. Retrieved October 11, 2017, from https://www.wto.org/english/res_e/booksp_e/world_trade_report13_e.pdf

WTO [World Trade Organization] (2014). World trade report 2014: Trade and development: recent trends and the role of the WTO. Retrieved October 11, 2017, from https://www.wto.org/english/res_e/booksp_e/world_trade_report14_e.pdf

Yean, T. S., \& Heng, L. W. (2011). Industrial deepening in Malaysia: Policy lessons for developing countries. Asian Development Review. 28(2), 88-109.

Zhang, H., \& Xia, M. (2017). The Effects of Technology and Division of Labor on Value Added Rates - An Analysis Based on Input-Output Model. 25th International Input-Output Conference \& 7th Edition of the International School of I-O Analysis, June 19-23, 2017, Atlantic City, New Jersey, USA.

\section{Copyright Disclaimer}

Copyright for this article is retained by the author(s), with first publication rights granted to the journal.

This is an open-access article distributed under the terms and conditions of the Creative Commons Attribution license (http://creativecommons.org/licenses/by/4.0/). 